\title{
MANAGEMENT OF EDUCATOR AND EDUCATION STAFF HUMAN RESOURCES IN SMK BINA SEJAHTERA 4 VOCATIONAL SCHOOL BOGOR
}

\author{
M. Hidayat Ginanjar, ${ }^{1}$ Rahman, ${ }^{2}$ Muhamad Syukur ${ }^{3}$ \\ ${ }_{1,2}$ Dosen Jurusan Tarbiyah STAI Al-Hidayah Bogor \\ ${ }^{4}$ Dosen Jurusan Tarbiyah UIN Syarif Hidayatullah Jakarta \\ e-mail: m.hidayatginanjart@gmail.com \\ e-mail: rahmantiro72@gmail.com \\ e-mail:msyukur0101@gmail.com
}

\begin{abstract}
This study aims to determine the management of human resources, especially educators and education staff in vocational high schools. The object of this research is SMK Bina Sejahtera 4 Bogor City. The focus of this research is laid out into several sub-focus research problems such as; (1) The system for recruiting human resources for teachers and education personnel, (2) The system for developing and enhancing the competence of human resources for educators and educational personnel, (3) Barriers and solutions for HR development. This research method uses qualitative methods with data collection through observation, interviews, and documentation study. The main informant of this research is the principal, and the supporting informants are teachers and staff. The data analysis technique used by the author is triangulation which includes triangulation of data, methods, and sources. The research results include; (1) The recruitment system for teachers and education staff is already running well,

(2) The HR development system for teachers and education staff is quite good and by their professionalism, (3) There are still a few obstacles in developing HR competencies, especially the limited cost of education. As an alternative solution made by the principal of SMK Bina Sejahtera 4 is involving teachers in various training activities such as; subject teacher deliberation (MGMP), principal work deliberation (MKK), and training activities organized by the Bogor City Education Office.
\end{abstract}

Keywords: management, educators, education staff, bina sejahtera

Penelitian ini bertujuan untuk mengetahui pengelolaan Sumber Daya Manusia khususnya pendidik dan tenaga kependidikan di Sekolah Menengah Kejuruan. Yang menjadi objek penelitian ini SMK Bina Sejahtera 4 Kota Bogor. Fokus penelitian dijabarkan menjadi beberapa sub fokus masalah penelitian, antaralain: (1) Sistem perekrutan SDM pendidik dan tenaga kependidikan, (2) Sistem pengembangan dan peningkatan kompetensi SDM pendidik dan tenaga kependidikan, (3) Hambatan dan solusinya dalam pengembangan SDM. Metode penelitian ini menggunakan metode kualitatif dengan pengumpulan data melalui observasi, wawancara, dan studi dokumentasi. Informan utama penelitian adalah kepala sekolah, dan informan pendukung yaitu guru, dan pegawai. Adapun teknik analisis data yang digunakan penulis adalah triangulasi, meliputi antaralain: triangulasi data, metode, dan sumber. Hasil penelitian antara lain: (1) Sistem perekrutan SDM Guru dan Tenaga Kependidikan sudah berjalan dengan baik, dan (2) Sistem pengembangan SDM guru dan tenaga kependidikan cukup baik dan sesuai profesionalitasnya, dan (3) Masih terdapat sedikit hambatan dalam mengembangkan kompetensi SDM terutama keterbatasan biaya pendidikan. Sebagai alternatif solusi yang dilakukan kepala SMK Bina Sejahtera 4 yaitu melibatkan para guru dalam berbagai kegiatan pelatihan, diantaranya; musyawarah guru mata pelajaran (MGMP), musyawarah kerja kepala sekolah (MKK), dan kegiatan-kegiatan Diklat yang diselenggarakan oleh Dinas Pendidikan Kota Bogor.

Kata kunci: manajemen, pendidik, tenaga kependidikan, bina sejahtera 


\section{INTRODUCTION}

In this millennial era, human resource management is one of the knowledge that everyone needs to learn and practice, especially in an organization, whether it is organizations engaged in services, business, social, or non-profit institutions such as course, schools, and universities.

In this millennial era, human resource management is one of the knowledge that everyone needs to learn and practice especially in an organization whether it is organizations engaged in services, business, social, or non-profit institutions such as course, schools, and universities.

The most important thing in advancing schools in human resources management is the teaching staff. By having educators who are competent in their fields they will be able to make very useful contributions to the sustainability/progress of a school (Suparto, 2016: 276).

Human resources are the most important element because humans are the subject of running the organization. Humane treatment is needed. The activities related to HR management start from recruitment, which consists of evaluating the condition of the workforce, distributing job advertisements, testing, placement, orientation, specifications, payroll systems, training, awarding, and promotion (Fuad Gani \& Budiantoro, 2016: 35).

Leadership needs to be considered in HR management because a leader is a factor that can determine the course of an organization to achieve its goals. Whatever a person's leadership style, the position is expected to direct workers to carry out their duties in mutually agreed ways. He is also the ultimate decision-maker or mediates in a conflict

Also, the complexity of work in this globalization era increasingly requires workers to have skills in using computers and also the sensitivity of workers in the surrounding environment. This sensitivity needs to be familiarized with each individual as part of a modern way of thinking, to be more adaptive and responsive to change.

An employee has a meaningful contribution value to the institution if his presence is required, has significant benefits to the productivity of the institution, and his activities are in the chain of the integrity of the institutional system. The success rate of human resource management in an institution can be assessed from its accuracy in carrying out human resource management functions. The benefit of an employee must be seen from the interests and meaning for himself, the productivity of the institution, and the parties who get the services of the institution. 
To achieve optimal meaningfulness of human resources we need management with clear objectives. The management objectives can be seen from the lowest level, namely; the personal level (personality objective), moving up to a higher level, namely functional objective, continue to organizational objective, and the last, namely national and international public service purposes (society objective). Due to differences in the orientation of human resource management objectives, it will have an impact on how management activities are carried out by an institution. To make human resources function effectively and efficiently it is necessary to have good human resource management starting from planning to the final stage of the management function.

Based on the result of observations in December 2020, one of the schools in Bogor that now has been concerned with HR development is SMK Bina Sejahtera 4 which is on Jalan Raya Dramaga Km 7, Margajaya Village, West Bogor, Bogor. This school has excellence in educating students to achieve their goals, supported by several human resources (educators and education personnel) and adequate learning facilities. SMK Bina Sejahtera 4 was founded by Bina Sejahtera Foundation (YBS) which is in JL. Jend. Ahmad Yani Blk. 64 Bogor and was founded by Mr Drs. H. Utang and Mrs Hj. Muntini in 1993. Under their leadership, then YBS achieved good progress and continued to develop the establishment of the school of SMK Bina Sejahtera 4. This school started implementing education in the 2014/2015 school year. In 2016 SMK Bina Sejahtera 4 was accredited "A" by the National Accreditation Board (BAN). And the school vision is the realization of an independent, intelligent, creative, and human competent based on the foundation of faith and piety. This vision then elaborated with its mission, such as (1) improving the quality of quality and competitive education to form a religiously moral, intelligent, and cultured Indonesian personality and having an international outlook, (2) implementing integrated learning between excellent school and qualified education according to the demands of the needs, especially in the business world and the industrial world, (3) implementing life skills programs that are by real needs through education, (4) fostering an attitude of responsibility, discipline, and independence in every activity, (5) implementing increasing human resource competence through continuing education and training, (6) developing students' talents and skills so that they can produce creative values, (7) implementing character education by integrating Islamic religious values and exemplary.

Since 2015 until now, SMK Bina Sejahtera 4 is led by Mr Ir. H. Nugraha Setialaksana, one of the founders of SMK Bina Sejahtera Kota Bogor who joined in 1996 was very 
concerned about developing human resource competencies, especially teachers and education personnel.

Based on these problems the main purpose of writing this article is to describe the results of research on the management of human resources for educators and education staff at SMK Bina Sejahtera 4 Bogor.

\section{LITERATURE REVIEW}

\section{HR Recruitment}

According to Veithzal Rivai, recruitment is a process of determining and attracting applicants who can work in a company/organization. This process begins when applicants are searched for and ends when applications are submitted/submitted. The result is a group of applicants for prospective employees/new workers to be selected (Veithzal Rivai, 2006: 158). Agreeing with Rivai, Muslimah said that labour recruitment is needed to screen applicants who want to apply. In an organization, this recruitment is an important process in determining whether or not applicants will apply to the organization (Muslimah, 2019: 32).

To have qualified teachers depends on the quality of the recruitment process. The better the process, the more likely it is that individuals who meet the qualifications expected by the school will be found. The recruitment of educational personnel is an activity to meet the needs of educational personnel at educational institutions, both in number and in quality, for recruitment activities are needed (Rohmatun Lukluk Isnaini, 2015: 111).

One way to find qualified human resources is through a recruitment system. Talking about the recruitment system is very interesting to observe. The recruitment system applied by each organization, both public and private, is different from one another. Recruitment is the process of seeking, finding, and attracting applicants to be employed in an organization. Recruitment is essentially a process of determining and attracting capable applicants to work in a company. This process begins when applicants are sought and ends when applications are submitted. The result is a group of applicants for new employee candidates to be selected.

According to Qurratu A'yun, the recruitment process for new educators is carried out selectively because recruitment is very important for the future of students, through the recruitment process, schools get qualified human resources (Qurratu A'yun, et al, 2019: 854). 
To obtain qualified human resources and insufficient numbers, a recruitment system is needed that can be used in the withdrawal process. For organizational effectiveness and efficiency to be realized, a proper recruitment process based on careful planning is required.

According to Kholidah, there are two objectives in recruitment activities, namely; First, schools/madrasahs have a great opportunity in determining the choice of prospective educators who meet qualification standards. From a series of recruitment activities that are carried out, it can find and attract applicants to demonstrate the abilities and knowledge that applicants have by what is expected that the recruitment organizing madrasah is in line with the provisions that have been identified. Schools/Madrasahs can determine the qualifications of prospective applicants according to the wishes of the madrasah which are determined through recruitment planning. Thus, madrasahs can find prospective applicants who meet the qualifications of teaching staff needed by schools/madrasahs through the recruitment process. Second, schools/madrasahs will find prospective educators of the highest and the best quality (Zakiyah Kholidah, 2018: 239). Another opinion suggests, the high and low quality of education is largely influenced by the quality of the learning process carried out by the teacher because the teacher directly provides guidance and assistance to students to achieve educational goals (Rokhmaniyah, 2017: 74).

Thus, seeing the importance of the quality of teaching staff and education staff in achieving the success of educational goals, educational institutions are very dependent on the recruitment process carried out by these educational institutions.

\section{HR Competency Development}

Schools in achieving their goals are often faced with obstacles in the form of the low quality of the teacher works, which are indicated by several schools where the number of teachers` teaching is very small (does not match with the real number of teaching hours), effectiveness, efficiency, and education standardization that are still not optimized, 2019: 174).

Educators (teachers) are a key element in the education system, especially in schools (Ministry of National Education, 2008). This is because teachers are the central point in renewing and improving the quality of education, in other words, one of the important requirements for the realization of qualified education is if its implementation is carried out by educators whose professionalism can be relied on (Krismiyati, 2017: 45). 
Educators and education staffs are human resources who have an important role in creating a good atmosphere during the learning process. In this case, educators are teachers, while education staffs are administrative staff and other non-teaching employees. Educators and education staff who comply with standards and perform their duties effectively will create a learning process that is by the goals of the school to be achieved (Riza Nur Fadila, et al. 2020: 82).

Therefore, human resources are really needed at this time are those competent in mastering technology quickly, adaptively, and responsively to technological changes. In these conditions, personal integrity is increasingly important to calm competition.

Human resource management (HRM) is a strategic area of the organization. Human resource management must be seen as an insight development of the traditional view of managing people effectively. And for that, it requires knowledge of human behaviour and the ability to manage it (Edi Sutrisno, 2009: 5).

Human resource management-HRM refers to policies, practices, and systems that affect employee behaviour, attitudes, and performance. Many organizations refer to the HRM concept as "human practices" (Nur Ulfatin \& Teguh Triwiyanto, 2016: 2). HRM is the process of obtaining, training, assessing, and compensating employees, and taking care of their work relationships, their health and safety, and matters related to justice (Dessler. 2015: 4). HRM discusses that human is the most important element in any organizations. The success of an organization in achieving the objectives and its ability to face various challenges, both external and internal is largely determined by the ability to manage human resources appropriately. The problems of self-development, fairness, expectations, and work suitability with one's characteristics and organizational behaviour problems are important parts of human resource management (Siagian, 2014: 40).

The focus of HRM is in managing human resources in the dynamic interaction between organizations and workers who often have different interests. According to Stoner (1995), HRM includes the productive use of human resources in achieving organizational goals and satisfying the needs of individual workers.

So, HRM can also be an activity of planning, procuring, developing, maintaining, and using HR to achieve goals both individually and in an organization. Even though the objects are both human, in essence, there are essential differences between human resource management and labour management or personnel management. 
In the personnel management, there is an understanding that personnel or employees are only considered as one of the production factors where the energy must be used productively for the achievement of institutional goals, while in the term of HRM, it implies that HR or employees in that institution are assets (wealth, valuable property) which must be cared for, and their needs met properly. In HRM, employees are essentially determined, not only as an object of achieving organizational goals but also considered as a subject whose role is to determine whether or not the institutional goals are achieved.

Human resource management (HRM) is part of organizational management that focuses on the element of human resources. Human resource management must manage the human element properly to find a workforce who is satisfied with their work. According to Umar (1999), human resource management functions can be grouped into three main functions, namely; (1) Managerial functions: planning, organizing, directing, and controlling, (2) Operational functions: procurement, development, compensation, integration, maintenance, and termination of employment, and (3) The third function is the position of human resource management in achieving the goals of the company organization in an integrated manner.

Based on the theoretical review above, it can be concluded that the management and utilization of individual-existing resources (employees/staff/teachers/education personnel) are carried out by a leader. And the management/utilization is developed optimally to achieve organizational goals and the development of individual human beings in an integrated manner.

\section{METHODS}

This study aims to determine the management of human resources, especially teachers and education staff at SMK Bina Sejahtera 4 Bogor and its obstacles. The method used in this research is a qualitative method, which is a research and understanding process based on a methodology that investigates social phenomena, events, natural behaviour of people being observed and produces descriptive data in the form of written or spoken words of the people. In this approach, the researcher creates a complex and comprehensive picture, examines words, provides a detailed report of the informant's viewpoint, and conducts studies on natural situations (Creswell, 1998: 15). According to Moleong, qualitative research is to understand the phenomena experienced by research subjects holistically by describing them in the form of words and language, in a special natural context by utilizing various scientific methods (Moleong, 2017). 
The approach used is direct research that observing the object as the target of the research, namely the process and implementation of human resource management for educators and education staff at SMK Bina Sejahtera 4 Bogor. This research process includes several phases, namely; (1) the researcher as the subject, (2) the paradigm and theoretical point of view, (3) the research strategy, namely a case study of the role of the principal in managing and developing the human resources of teachers and education personnel, (4 ) Data collection, and analysis methods, through interviews, observations, documents, notes, visuals, data processing, and textual analysis, (5) Interpretation and presentation art, including criteria for assessing adequacy, interpretation strategies and writing as interpretation. (Norman K. Denzin and Yvonna S.L, 2009: 16).

Five important components of a case study research design include (1) research questions, (2) propositions of inquiry on the topic of discussion, (3) units of analysis, (4) logic that relates data to propositions, and (5) criteria for interpreting the findings. The question approach is how and why (Robert. K. Yin, 2009: 27).

Qualitative research with a natural approach emphasizes the researcher as a key instrument in which the researcher reveals the conditions experienced during research in real and natural. The data collection was carried out by triangulation (combined) while the data analysis was inductive. And the results of the study emphasized to meaning (Sugiyono, 2013: 8).

The research period has been conducted from July to December 2020. The research preparation included; Initial observation of the research location and collecting data/information related to the focus of the problem under study, then looking for concepts related to research problems through literature study. The research procedure includes; (1) data collection through site visits (grand tour observation) to get an overview of the research context, (2) interviews with key and supporting informants, (3) processing data from research results and analysis through data triangulation, accountability, and acceptability, (4) analysing findings and discussion, (5) concluding research results and publishing them to the public.

\section{RESULTS AND DISCUSSION}

\section{HR Candidate Recruitment and Selection System}

Based on the results of observations and interviews show that the recruitment system of employees at SMK Bina Sejahtera 4 is carried out in two ways; (1) internal institutions, 
namely permanent teacher relations, honorarium staff who has sufficient service periods, and show dedication and good performance they can be selected as permanent teachers of the foundation, (2) publication in partner institutions that have collaborated, (3) open channels, namely through advertising in the mass media, and (4) rotating employees within the foundation. Meanwhile, the aspect of assessment that is most considered for prospective teachers is educational linearity and expertise (Interview with Ir. H. Nugraha, Principal of SMK BS, 19 December 2020).

Singodimedjo (2000), said that recruitment is a process of finding, finding, and attracting applicants to be employed in an organization. The process of recruiting human resources should not be neglected, this is to prevent a mismatch between what is desired and what is obtained. It means that the organization does not get the right employees, in terms of both quality and quantity. If it does not happen as expected by the organization, it will fail. To obtain high-quality human resources and the appropriate amount, a recruitment method is needed that can be used in the withdrawal process based on really mature planning.

The following elements must be planned and structured before starting the recruitment process, some elements in question are (1) determining needs (formation), (2) recruitment policy, (3) roles and responsibilities, (4) candidate sources, (5) material and literature.

Based on the information of the main informant, that the procedure for admitting prospective employees at SMK Bina Sejahtera is carried out by, among other things; (a) applications that are sent directly by prospective employees are selected with certain conditions, while applicants from the mass media can be sent directly via email to the HR management department, (b) applicants who are deemed to meet the criteria are summoned to be selected, (c) Conducting selection by writing, reading the Koran, physic and psychological tests and other interviews conducted by the leadership of SMK Bina Sejahtera 4 (Interview with Ir. H. Nugraha, Principal of SMK BS, December 19, 2020).

In the recruitment and appointment of new employees, there are several regulations at SMK Bina Sejahtera 4 vocational school Bogor, including; (1) Employees acknowledge that issues of recruitment, appointment, and placement/transfer of employees are the full rights and authority of the foundation, (2) Every new employee before being appointed as permanent employees are obliged to undergo 3 months of the probation unless otherwise specified in the employment offer letter, (3) During the probation period the employment relationship can be terminated at any time by each party, (4) If the employee is declared to 
have passed the probation period and is accepted as a permanent employee the HR department will provide a letter of appointment. Employee tenure is calculated from the first day of probation, (5) Employee placement is adjusted to job needs/formation by taking into account the linearity of education, competence, and expertise of prospective employees.

\section{Competency Development of Human Resources for Educators and Education Personnel}

Based on the results of interviews with key informants, the development of educators' competence at SMK Bina Sejahtera 4 vocational school Bogor is carried out in several ways, including; (1) organizing in-house training (IHT) activities, (2) collaborating with the business world and the industrial world (DUDI), (3) organizing training/PKB organized by Bogor City Education Office, (4) organizing/involving teachers in various school activities, (5) providing financial assistance for further studies for employees with good performance. This was done to prepare the management cadres even though the allocation was limited (Interview with NS-Principal of SMK Bina Sejahtera 4, 19-12-2020).

These findings are in Hasan Basri's opinion, who said that human resource development is a systematic and planned set of activities designed to facilitate employees with the skills needed to meet job demands, both now and into the future (Hasan Basri \& Rusdiana, 2015: 14).

In this principle, human potential involves two aspects, namely the aspects of quantity and quality. The qualified aspect can be only achieved by developing human resources because human resources are the most influencing factor in life. The human ability to influence nature shows that the position of human resources is very central.

For this reason, human potential needs to be developed through the process of developing human resources in the context of the realization of a complete human being or a quality human being by the nature and goals of Indonesia's national development. One of the goals that need to be built is the resource that comes from humans, and the humans who have that resources must be empowered and developed

According to Soekidjo Notoatmodjo (1999), as quoted by Hasan Basri, human resource development is the process of planning, training, and managing personnel or employee's education to achieve optimum results. This result can be in the form of services, objects, or money. 
So, it can be said that human resource development is an effort to provide education and training for employees to increase the ability in their field of work to achieve the goals set by the foundation /organization.

The process of developing human resources begins with strategic planning and SMK that determines the place of business activity and the number of resources needed. In other words, the starting point of the human resource program lies in the SMK strategy plan which is transferred to the human resource plan regarding how much and what kind of workforce is needed in the future. It means that the role of HR development strategies should begin with an analysis of current HR competencies, then compare them with needs.

For the progress of an organization, human resource development is so important for a leader. As Hasibuan's opinion states that HR development has the following objectives, namely; (1) Increasing work productivity, (2) Increasing efficiency, (3) Reducing damage, (4) Reducing employee accident rates, (5) Improving better service, (6) Employee morale is better, (7) The opportunity to improve employee careers is greater, (8) Technical skills, human skills, and managerial skills are getting better, (9) Leadership of a manager will be better, (10) Remuneration increases because greater job potential, (11) Providing better benefits for the consumer community because they will get better quality goods or services (Hasibuan, 2003: 70-72).

Based on the results of observations and interviews, the leadership of SMK Bina Sejahtera 4 vocational school Bogor has made and established regulations regarding the importance of human resource development in both teacher and educational staff formation based on aspects of self-potential, capabilities and needs of the foundation, while internal employees are prioritized to fill vacancies. However, Vocational School leaders can recruit employees from outside the foundation. Career development at SMK Bina Sejahtera is a shift from one position to another structurally higher level by the compensation and benefits policy at the foundation. The criteria considered in assessing HR candidates who will fill a position at least include; educational linearity, skills/expertise, level of maturity, competence, work experience, and other criteria deemed necessary by the foundation.

Education and training in human resource development have at least two main dimensions, namely the personal dimension and the organizational dimension. Both must be developed in a precise, simultaneous, and sustainable manner. In this way, the company can become a learning organization and grow and develop because it is supported by employees 
who constantly learn new things and apply them to improve quality and providing the best services.

In providing educational services and developing human resources, educational institutions should consider that excellence is a very important thing to prioritize today (Muslihat \& Ginanjar, M.H 2019: 105).

Based on the results of observations and interviews at SMK Bina Sejahtera 4 vocational school Bogor, it is found that the development and training carried out by the leadership of SMK Bina Sejahtera 4 has the following objectives; (1) As an effort to improve the ability and work skills of employees, as well as pay attention to the need for human resource development for the long term, (2), provide an opportunity for every employee (teacher and student) who has the requirements to take part in education and training organized by SMK or by outsiders by the policies of school/foundation leaders, (3) providing opportunities for employees (teachers and staff) to attend education by the foundation's policies (Interview with Ir. H. Nugraha Setialaksana, Principal of SMK Bina Sejahtera 4, December 19, 2020).

The findings above are in line with Salahuddin's opinion who said that "Educational programs to improve the quality of human resources are very important because there are many problems in government institutions, social institutions, and various activities in a society which effectiveness depends on the quality of human resources, both in intellectual ability and moral integrity as his responsibilities". (Salahuddin, et al, 2000: 2). Likewise, the opinion of Makbullah says that improving the quality of education is a more effective and efficient work process followed by competent human resources with high loyalty and fighting power, of course, it will result in an increased performance which leads to customer satisfaction (Deden Makbullah, 2011: 4).

Education and training organized by SMK Bina Sejahtera 4 vocational school Bogor is an effort to develop human resources, especially for the development of aspects of intellectual abilities, personality, and expertise for employees in a certain period aimed at improving specific competencies or skills. A well-organized and systemized human resource development program is believed to have a positive impact on the progress of schools today and in the future.

Some of the achievements achieved by SMK Bina Sejahtera 4 include; (1) the $1^{\text {st }}$ winner in the student competency competition in the field of engineering at the West Java provincial level in 2018, (2) the $3^{\text {rd }}$ winner in the student competition, (3) the $1^{\text {st }}$ winner in electric 
welding LKS, (4) the $1^{\text {st }}$ winner of Martial Arts, (5) PMR as the $1^{\text {st }}$ winner, (6) and every year one of the alumni of SMK Bina Sejahtera 4 is accepted to work in Japan.

\section{Barriers to Competency Development of Human Resources for Educators and Education Personnel}

Based on the results of the interview, there are few obstacles in developing the competence of human resources for teachers and education staff at SMK Bina Sejahtera 4 vocational school Bogor, there is still a limited budget for funding training activities to improve the competence of educators and educational personnel in the SMK Bina Sejahtera 4 vocational school Bogor. Solutions What is done by the principal in overcoming these inhibiting factors is to involve teachers in various training activities organized by Bogor City Education Office, including; Subject Teacher Deliberation (MGMP), Principal Work Deliberation (MKKS), Workshops, and Seminars.

\section{CONCLUSIONS}

Based on the research findings and discussion regarding the management of human resources for educators and education staff at SMK Bina Sejahtera 4 Bogor, it can be concluded as follows;

First; the recruitment system of human resources for teachers and education staff is already running well. However, there are still several things that need to be considered, including the need for selective and precise recruitment in recruiting employees, in staff assignments that are adjusted to their respective fields, and in HR procurement or restructuring for vacant positions. Regarding this, SMK Bina Sejahtera 4 vocational school Bogor still needs to recruit teachers and education staff according to their qualifications by paying attention to the qualifications and backgrounds of prospective employees to adjust the job field in which they will be placed.

Second; The human resource development system for Teachers and Education staff is quite good and according to their professionalism, but for the career advancement of employees (teachers and education personnel), attention and support from the leadership are still needed, for example through assistance for further study fees, being involved in various training, workshops, and seminars. The workshops here is intended so that the planning and development of human resources at SMK Bina Sejahtera 4 vocational school Bogor can reach the progress as the vision and mission set by the institution. 


\section{REFERENCES}

A'yun, Qurratu, dkk. (2019). Rekrutmen Tenaga Pendidik Di SMA. Jurnal Pendidikan: Teori, Penelitian, dan Pengembangan, 4(7).

Basri, Hasan dan Rusdiana. (2015). Manajemen Pendidikan dan Pelatihan. Bandung: CV Pustaka Setia.

Fadila, Riza Nur, dkk. (2020). Efektivitas Pengelolaan Sumber Daya Sekolah Dalam Meningkatkan Mutu Pendidikan. Jurnal Akuntabilitas Manajemen Pendidikan, 8(1).

Gani, Fuad dan Budiantoro. (2016). Manajemen Perkantoran Modern. Jakarta: Rajawali Pers.

Hasibuan, Malayu. (2003). Manajemen Sumber Daya Manusia. Jakarta: PT.Bumi Aksara.

Isnaini, Rohmatun Lukluk. (2015). Implementasi Rekrutmen Guru Di SD Ta'mirul Islam Surakarta (Kajian Manajemen SDM Di SD Islam). Jurnal Pendidikan Agama Islam, XII(1).

Kholidah. (2018). Sistem Rekrutmen Tenaga Pendidik di Madrasah Swasta. AL-HIKMAH: Jurnal Studi Islam, 8(2).

Krismiyati. (2017). Pengembangan Sumber Daya Manusia dalam Meningkatkan Kualitas Pendidikan di SD Negeri Inpres Angkasa Biak. Jurnal Office, 3(1).

Makbullah, Deden. (2011). Manajemen Mutu Pendidikan Islam, Model pengembangan Teori dan Aplikasi Sistem Penjaminan Mutu. Jakarta: PT. RajaGrafindo Persada.

Moleong, Lexy J. (2017). Metodologi Penelitian Kualitatif. Bandung: PT Remaja Rosdakarya.

Muslihat \& Ginanjar, M.H. (2019). Pengelolaan Sumber Daya Manusia Di SMP Hasmi Islamic Boarding School Tamansari Bogor. Islamic Management: Jurnal Manajemen Pendidikan Islam, 2(1).

Muslimah. (2019). Rekrutmen Strategi Dalam Manajemen SDM. Jurnal At-Ta'lim, 1(1).

Purba, Zubel. (2019). Pengaruh Kepemimpinan Transformasional Dan Lingkungan Kerja Terhadap Kualitas Kerja Guru Sekolah Menengah Atas Swasta Zona I Jakarta Utara. Jurnal Manajemen Pendidikan.

Rivai, Veithzal. (2006). Manajemen Sumber Daya Manusia untuk Perusahaan: dari Teori ke Praktik. Jakarta: PT Raja Grafindo Persada.

Rokhmaniyah. (2017). Manajemen Sumber Daya Manusia Untuk Mencapai Pendidikan Yang Berkualitas Di Sekolah Dasar. DWIJACENDEKIA: Jurnal Riset Pedagigik, $1(1)$.

Salahuddin, dkk. (2018). Meningkatkan Mutu Pendidikan Melalui Sumber Daya Manusia Dan Sarana Prasarana di MTsN Banjar Selatan 2 Kota Banjarmasin. Administraus: Jurnal Administrasi Pendidikan, 2(1).

Suparto. (2016). Manajemen Sumber Daya Manusia (SDM) Guru Dalam Peningkatan Mutu Pendidikan di Madrasah Ibtidaiyah Al-Islam Kota Bengkulu. An-Nizom, I(3).

Sugiyono. (2013). Metode Penelitian Kuantitatif, Kualitatif dan R \& D. Bandung: Alfabeta, Cet ke-16. 
Sutrisno, Edy. (2009). Manajemen Sumber Daya Manusia, Jakarta: Kencana Prenada Media Group.

Ulfatin, Nurul dan Triwiyanto Teguh. (2016). Manajemen Sumber Daya Manusia Bidang Pendidikan. Jakarta: Rajawali Pers. 